\begin{tabular}{|l|l|l||}
\hline \multicolumn{2}{|c|}{ PublisherInfo } \\
\hline \hline PublisherName & $:$ & BioMed Central \\
\hline \hline PublisherLocation & $:$ & London \\
\hline \hline PublisherImprintName & $:$ & BioMed Central \\
\hline \hline
\end{tabular}

\title{
Mammary Gland Cell Death Also Involves Lysosomal Autophagy
}

\begin{tabular}{|l|l|l||}
\hline \multicolumn{2}{|c||}{ ArticleInfo } \\
\hline \hline ArticleID & $:$ & 2424 \\
\hline \hline ArticleDOI & $:$ & $10.1186 /$ bcr307 \\
\hline \hline ArticleSequenceNumber & $:$ & 1 \\
\hline \hline ArticleCategory & $:$ & Non-peer-reviewed research \\
\hline \hline ArticleFirstPage & $:$ & 1 \\
\hline \hline ArticleLastPage & $:$ & 7 \\
\hline \hline & & RegistrationDate $:$ 2001-5-8 \\
& $:$ & Received \\
\hline ArticleHistory & & Accepted \\
& $:$ 2001-5-8 \\
\hline \hline ArticleCopyright & $:$ & BioMed Central Ltd2001-10 \\
\hline \hline ArticleGrants & $:$ & \\
\hline \hline ArticleContext & $:$ & 13058 \\
\hline \hline
\end{tabular}


Reginald Halaby, ${ }^{\text {Aff1 }}$

Corresponding Affiliation: Aff1

Email: halabyr@mail.montclair.edu

Aff1 Department of Biology \& Molecular Biology, Montclair State University Upper Montclair, NJ 07043

\section{Abstract}

The mammary gland undergoes apoptosis when estrogen ablation occurs, either naturally or enforced. The gland is known to execute the apoptotic process post weaning. Although the involuting mammary gland displays the characteristic biochemical features of apoptosis, including DNA fragmentation, chromatin condensation, and the formation of apoptotic bodies, it also shows evidence of an autophagic death. In this report, apoptosis of the gland was induced by removing the pups from their nursing mothers. In particular, we show that lysosomes increased in size and number, and moved from basal to apical regions in dying rat mammary gland cells. Lysosomal enzyme activities were significantly greater in degenerating mammary gland (day 4 post weaning) epithelial cells when compared with day 0 gland cells. Moreover, these hydrolases were responsible for degrading cytosolic and nuclear components, and thus the whole cell. Taken together, our results demonstrate that the mammary gland dies by lysosomal autophagy in addition to apoptosis during post-lactational involution. Our studies indicate that the lysosomal compartment may serve as an important target organelle for the creation of specific, effective, and novel therapies for breast cancer.

\section{Keywords}

cell death, involution, lysosomal enzymes, mammary gland, postlactation

\section{Introduction}

Considering the coordinated regulation between cell survival and cell death that must be maintained for normal growth, it is not surprising that apoptosis has emerged as a fundamental component in the regulation of tissue homeostasis. Therefore, it is feasible that cell survival and apoptosis are regulated through a common pathway; however, such a divergent mechanism has not been previously described [1]. Apoptosis of the secretory mammary epithelium occurs during the post-lactational involution of the mammary gland. This is evidenced by morphological and biochemical changes that are characteristic of this type of cell death $[2,3]$. The involution is characterized by an increase in the number of apoptotic 
events in the luminal epithelial layer of the lobulo-alveolar compartment soon after weaning [4, 5]. This is followed by proteolytic degradation of supporting basement membrane and major remodeling of the gland. There is also marked activity of lysosomal enzymes during apoptosis of the mammary gland [6, 7]. The expansion of the lysosomal compartment is paralleled by a substantial increase in the synthesis, secretion, and activity of several lysosomal hydrolases that degrade components of the basement membrane $[8,9]$. Lysosomes contain over 40 lytic enzymes that can degrade all classes of macromolecules.

Maintenance of the differentiated structure of the gland and survival of the secretory epithelium during lactation depends upon a combination of extracellular survival signals originating from neighboring basement membrane, cell adhesion molecules, lactogenic hormones, and as yet, undefined local factors [2]. Disruption of these signals is known to potentiate apoptosis of mammary epithelial cells, but the downstream effectors of these pro-apoptotic signals remain elusive. For instance, in the absence of estrogen, the secretory epithelial cells of the mammary gland undergo successive waves of cell death coincident with extensive reorganization of the surviving tissue.

In this report, we show that the mammary gland displays the characteristic morphological features of apoptotic cells in response to hormone ablation induced by weaning. In addition, we demonstrate the expansion of the lysosomal compartment and that the enzymatic activities of several lysosomal hydrolases are significantly elevated during apoptosis in the mammary gland. These results indicate that lysosomes are actively involved in degrading the post lactating gland as it involutes.

\section{Materials \& methods}

\section{Rearing of the animals and isolation of the mammary gland}

The Sprague-Dawley rat is highly regarded for studies designed to investigate the effects of endocrine modulation on mammary gland apoptosis and carcinogenesis. Nursing Sprague-Dawley female rats were obtained with litters from Taconic (Germantown, NY). The animals were allowed free access to food and water. The mothers were allowed to nurse their pups for 3 weeks. The pups were taken from the mothers at day 0 (lactating) and the involuting breast tissue was harvested following weaning. The excised tissue was fixed overnight in $4 \%$ paraformaldehyde at $4^{\circ} \mathrm{C}$, embedded in ophimum culting temperature, frozen in liquid nitrogen, and cut as $5 \mu \mathrm{m}$ sections onto poly-L-lysine coated slides from Sigma (St. Louis, MO).

\section{Lysosomal enzyme assays}


Acid phosphatase activity was measured using an assay from Sigma according to the manufacturer's instructions. Briefly, mammary glands were homogenized in $0.5 \mathrm{~mL} 0.9 \% \mathrm{NaCl}$ and the homogenates were clarified by centrifugation for $5 \mathrm{~min}$ at room temperature. The reaction mixture $[0.5 \mathrm{~mL}$ of pnitrophenyl phosphate (substrate), $0.5 \mathrm{ml}$ of $90 \mathrm{mM}$ citrate buffer, $\mathrm{pH} 4.8$, and $0.1 \mathrm{~mL}$ of homogenate] was incubated for $30 \mathrm{~min}$ at room temperature, and the reaction was terminated by the addition of $5 \mathrm{~mL}$ of $0.1 \mathrm{~N} \mathrm{NaOH}$. In alkali, liberated p-nitrophenol was measured spectrophotometrically at $410 \mathrm{~nm}$.

Cathepsin B was monitored using an enzymatic assay from Sigma according to the manufacturer's instructions. Mammary glands were homogenized in a buffer ( $\mathrm{pH} 6.0)$ containing $352 \mathrm{mM}$ potassium phoshate, $48 \mathrm{mM}$ sodium phosphate, and $4 \mathrm{mM}$ EDTA and clarified by centrifugation. The substrate was Na-CBZ-Arg-Arg-7-Amido-4-Methylcoumarin. The increase in fluorescence intensity for liberated 7-Amino-4-Methylcoumarin was recorded at the excitation wavelength of $348 \mathrm{~nm}$ and the emission at the wavelength of $440 \mathrm{~nm}$ for $5 \mathrm{~min}$.

$\beta$-N-acetylhexosaminidase (hexosaminidase) was also assayed according to Sigma's protocol. The glands were homogenized in $0.5 \mathrm{~mL} 0.9 \% \mathrm{NaCl}(\mathrm{pH} 4.8)$ and the homogenates were clarified by centrifugation for $5 \mathrm{~min}$ at room temperature. The substrate used was $\mathrm{p}$-nitrophenyl-N-acetyl- $\beta$ glucosaminide. The liberation of $\mathrm{p}$-nitrophenol and N-acetyl-D-glucosamine was measured spectrophotometrically at $410 \mathrm{~nm}$.

\section{Statistical analysis}

Student's $t$-test was used for the determination of statistical significance. Absorbance values for day 0 and day 4 involuting mammary gland extracts were considered statistically different at $P=<0.05$.

\section{Results and discussion}

In order to determine whether lysosomes play a role in post-lactational apoptosis in mammary glands, we used an in situ assay to localize these organelles. Acid phosphatase (AP), a marker enzyme for lysosomes [10], was used to identify lysosomes. The histochemical examination of AP in post weaning mammary glands is shown in Fig. 1. The gland was a healthy secretory gland at the onset of weaning, day 0 (Fig. 1, panels a and c). Negligible AP staining was detected on day 0 . However, four days post weaning (day 4), the mammary gland was highly vacuolated as evidenced by the loss of connective tissue (Fig. 1, panels b and d). Day 4 glands displayed marked positive AP staining, which is indicative of the presence of lysosomes, shown as dark granules (Fig. 1 panels $b$ and d). These results indicate that the gland is histolyzed by lysosomal enzymes, which can degrade all macromolecules.

Figure 1 Histochemical Appearance of Involuting Mammary Glands. Cell death in the mammary gland was induced by weaning the pups from their nursing moms. Day 0 and day 4 mammary gland extracts were assayed for the presence of lysosomes using an acid phosphatase (AP) assay. Day 0 glands displayed faint AP staining (panels a and c). In contrast, by day 4 the glands showed intense 
AP-positive staining and the cytoplasm was highly vacuolated (panels $b$ and d). Magnification: panels a and b, $250 \mathrm{X}$; panels c and d, $600 \mathrm{X}$.

[MediaObjects/13058_2001_Article_2424_Fig1_HTML.jpg]

We postulated that the increase in AP staining from the above studies could be the result of increased enzymatic activities of lysosomal hydrolases. Consequently, we determined the activities of three major lysosomal enzymes found in the mammary gland: cathepsin B, $\beta$-N-acetylhexosaminidase, and acid phosphatase. The activities of all of the enzymes investigated were statistically higher in day 4 involuting gland extracts compared to the values in day 0 gland extracts (Figs. 2,3,4). These data support the notion that the synthesis of these three lysosomal enzymes is upregulated during the cell death of the mammary gland.

Figure 2 Specific Activity of Acid Phosphatase in Mammary Glands Undergoing Cell Death. The values represent means $\pm \mathrm{SEM}$ of at least three independent experiments. All determinations were made in triplicate. Acid phosphatase enzymatic activity was statistically greater in day 4 involuting mammary gland extracts relative to the values from day 0 glands. The single ${ }^{*}$ indicates that values were statistically different at $P=<0.0001$.

[MediaObjects/13058_2001_Article_2424_Fig2_HTML.jpg]

Figure 3 Specific Activity of Cathepsin B in Mammary Glands Undergoing Cell Death. The values represent means $\pm \mathrm{SEM}$ of at least three independent experiments. All determinations were made in triplicate. The activity of cathepsin B was statistically elevated in day 4 involuting mammary gland extracts relative to the values from day 0 glands, at $P=<0.005$ (**).

[MediaObjects/13058_2001_Article_2424_Fig3_HTML.jpg]

Figure 4 Specific Activity of Hexosaminidase in Mammary Glands Undergoing Cell Death. The values represent means \pm SEM of at least three independent experiments. All determinations were made in triplicate. The activity of $\beta$-N-acetylhexosaminidase was statistically higher in day 4 involuting mammary gland extracts relative to the values from day 0 glands at $P=<0.009$ (***).

[MediaObjects/13058_2001_Article_2424_Fig4_HTML.jpg]

Apoptosis plays important roles in mammary development from early embryonic formation of the mammary gland to the regression that follows cessation of cycling [4]. The most dramatic occurrence of apoptosis is found during mammary involution. This is an important element in the developmental repertoire ensuring tissue homeostasis and proper disposal of cells that are no longer needed, such as milk-producing epithelial cells in the mammary gland after lactation. Involution of the mammary gland following weaning is divided into two distinct phases. Initially, milk stasis results in the induction of local factors that cause apoptosis in the alveolar epithelium [11]. Secondly after a prolonged absence of suckling, the consequent decline in circulating lactogenic hormone concentrations initiates remodeling of the mammary gland to the virgin-like state. Morphological studies and gene expression have suggested that apoptosis during involution is comprised of two phases: an early limited apoptosis in response to hormone ablation and later protease promoted widespread apoptosis in response to altered 
cell-matrix interactions and loss of anchorage [4]. Our data agree with those of Djonov et al. [12] who reported that the cell death that accompanies the involution of the mammary gland was only partly due to apoptosis.

\section{Conclusion}

The expression levels of lysosomal hydrolases have been used to monitor disease response and drug treatment in breast cancer patients [13]. These authors demonstrated that tamoxifen may have its antitumor effects by regulating the expression of several tumor marker enzymes, including those of lysosomal origin. The detection assays for these enzymes are inexpensive, quick, and are accurate. Our studies suggest that novel therapies for carcinomas of the breast may involve activation of lysosomal enzymes in tumor cells.

\section{References}

1. Vallorosi CJ, Day KC, Zhao X, Rashid MG, Rubin MA, Johnson KR, Wheelock MJ, Day ML: Truncation of the beta-catenin binding domain of E-cadherin precedes epithelial apoptosis during prostate and mammary involution. J Biol Chem. 2000, 275: 3328-3334. 10.1074/jbc.275.5.3328.

2. Walker NI, Bennett RE, Kerr JF: Cell death by apoptosis during involution of the lactating breast in mice and rats. Am J Anat. 1989, 185: 19-32.

3. Strange R, Li F, Saurer S, Burkhardt A, Friis RR: Apoptotic cell death and tissue remodelling during mouse mammary gland involution. Development. 1992, 115: 49-58.

4. Strange R, Metcalfe T, Thackray L, Dang M: Apoptosis in normal and neoplastic mammary gland development. Microsc Res Tech. 2001, 52: 171-181 . 10.1002/1097-0029(20010115)52:2<171::AIDJEMT1003>3.3.CO;2-K.

5. Lund LR, Romer J, Thomasset N, Solberg H, Pyke C, Bissell MJ, Dano K, Werb Z: Two distinct phases of apoptosis in mammary gland involution: proteinase-independent and -dependent pathways. Development. 1996, 122: 181-193. 
6. Helminen HJ, Ericsson JL, Orrenius S: Studies on mammary gland involution. IV. Histochemical and biochemical observations on alterations in lysosomes and lysosomal enzymes. J Ultrastruct Res. 1968, 25: $240-252$.

7. Helminen HJ, Ericsson JL: Quantitation of lysosomal enzyme changes during enforced mammary gland involution. Exp Cell Res. 1970, 60: 419-426.

8. Sensibar JA, Liu XX, Patai B, Alger B, Lee C: Characterization of castration-induced cell death in the rat prostate by immunohistochemical localization of cathepsin D. Prostate. 1990, 16: 263-276.

9. Guenette RS, Corbeil HB, Leger J, Wong K, Mezl V, Mooibroek M, Tenniswood M: Induction of gene expression during involution of the lactating mammary gland of the rat. J Mol Endocrinol. 1994, 12: $47-60$.

10. Pelletier G, Novikoff AB: Localization of phosphatase activities in the rat anterior pituitary gland. $\mathrm{J}$ Histochem Cytochem. 1972, 20: 1-12.

11. Nguyen AV, Pollard JW: Transforming growth factor beta3 induces cell death during the first stage of mammary gland involution. Development. 2000, 127: 3107-3118.

12. Djonov V, Andres AC, Ziemiecki A: Vascular remodelling during the normal and malignant life cycle of the mammary gland. Microsc Res Tech. 2001, 52: 182-189. 10.1002/

1097-0029(20010115)52:2<182::AID-JEMT1004>3.0.CO;2-M.

13. Thangaraju M, Rameshbabu J, Vasavi H, Ilanchezhian S, Vinitha R, Sachdanandam P: The salubrious effect of tamoxifen on serum marker enzymes, glycoproteins, and lysosomal enzymes level in breast cancer woman. Mol Cell Biochem. 1998, 185: 85-94. 10.1023/A:1006874005764.

This PDF file was created after publication. 